\title{
Erratum zu: Hornhaut Konfokal-Mikroskopie bei einer bilateralen Augenverletzung mit multiplen kornealen Fremdkörpern
}

\author{
Spektrum Augenheilkd (2011) 25: 231-233, \\ http://dx.doi.org/10.1007/s00717-011-0011-7 \\ L. Marsovszky, O. Maneschg, J. Németh, M. D. Resch \\ Klinik für Augenheilkunde, Semmelweis Universität Budapest, Ungarn \\ Eingegangen am 12. Mai 2011, angenommen am 27. Juni 2011
}

Das englischsprachige Abstract war in oben genanntem Beitrag unvollständig. Richtig muss es lauten:

Summary. Background: To analyse the morphological alterations, epithelial, infammatory and Langerhans cell density of cornea after longstanding bilateral multiple corneal metal foreign body (FB) injury.

Patient and Methods: Clinical records of a 36 years male patient were reviewed and confocal microscopy was performed two and six years after injury.

Results: Corneal FBs were situated in 10-156 $\mu \mathrm{m}$ depth. The wing cells were enlarged around FBs (right eye (RE): $3564 \pm 95$ / $\mathrm{mm}^{2}$, left eye (LE): $3624 \pm 73 / \mathrm{mm}^{2}$ ) on visit 1 , but their size de- creased by visit 2 (RE: $4121 \pm 69 / \mathrm{mm}^{2}$, LE: $3962 \pm 71 / \mathrm{mm}^{2}$ ). No inflammatory cell could be detected while Langerhans cells were randomly seen around FBs (RE: $26 \pm 4 / \mathrm{mm}^{2}$, LE: $30 \pm 7$ / $\mathrm{mm}^{2}$ on visit 1 , and RE: $37 \pm 4 / \mathrm{mm}^{2}$, LE: $39 \pm 5 / \mathrm{mm}^{2}$ on visit 2 respectively). Subbasal nerves were gracile, fragmented around FBs on visit 1 , and remained altered on visit 2 .

Conclusion: Our observation may prove that the corneal immune system can tolerate stable intracorneal metal FBs. The longstanding morphological alterations of epithelial cells and subbasal nerves mark the complex impact that such injury can cause.

Der Verlag bittet, den Fehler zu entschuldigen. 